\title{
Penerapan Path Analysis Kualitas Informasi terhadap Kepuasan Pengguna dan Intensitas Pengguna dengan Metode Delone \& Mclean Di Rumah Sakit Paru Jember Tahun 2017
}

\author{
Dony Setiawan Hendyca Putra ${ }^{1}$, Ady Seosetidjo ${ }^{1}$, Saiful Bukhori ${ }^{1}$ \\ Program Pascasarjana Ilmu Kesehatan Masyarakat, Universitas Jember ${ }^{l}$ \\ Email: donssend@gmail.com
}

\begin{abstract}
Hospital management information system is an effort to present accurate information, timely and as needed to support the process of management functions and decision making in providing health services at the Hospital. Manual data management, has many weaknesses, in addition to taking a long time, accuracy is also less acceptable, because the possibility of error is very large. Problems faced by users of hospital management information system obtained from interviews, among others: 1) Quality System: incompatibility of the system with the process of providing services to patients; 2) Intensity of User and System Users: the user does not implement hospital management information system with tablet (HP android) already provided by hospital management; 3) User satisfaction: the results of the survey researchers on subjectivity of users of hospital management information system of 9 heads of the installation states satisfied 4 people and the dissatisfied 5 people. The purpose of this study analyzed the effect of system quality on user satisfaction and user intensity. This research is a quantitative analytical research with cross-sectional approach. This study determines the hypothesis is any direct influence of exogenous variables of system quality on endogenous variables of user intensity. The results of this study quality of the information significantly affect the user satisfaction with black value of 4.16. User satisfaction significantly affects the intensity of users with black value of 3.28. So it can be concluded that the quality of information directly affects the user's intensity. Based on the results of these studies the hospital is advised to conduct the development of hospital management information system so that there are no complaints related to the quality of information.
\end{abstract}

Keywords: Hospital Management Information System, Information Quality, User Satisfaction and User Intensity.

\section{Pendahuluan}

Sistem

manajemen

merupakan suatu usaha untuk

menyajikan informasi yang akurat, tepat waktu dan sesuai kebutuhan guna menunjang proses fungsi-fungsi manajemen dan pengambilan keputusan 
dalam memberikan pelayanan kesehatan di Rumah Sakit.

Sistem informasi

manajemen rumah sakit dapat mengelola data pasien secara lebih baik sehingga lebih mudah dicari dan ditemukan. Pengelolaan data di rumah sakit merupakan salah satu komponen yang penting dalam mewujudkan suatu sistem informasi manajemen di rumah sakit. Pengelolaan data secara manual, mempunyai banyak kelemahan, selain membutuhkan waktu yang lama, keakuratannya juga kurang dapat diterima, karena kemungkinan kesalahan sangat besar. Dengan dukungan teknologi informasi yang ada sekarang ini, pekerjaan pengelolaan data dengan cara manual dapat digantikan dengan suatu sistem informasi dengan menggunakan komputer. Selain lebih cepat dan mudah, pengelolaan data juga menjadi lebih akurat.

Masalah yang dihadapi oleh pengguna sistem informasi manajemen rumah sakit didapatkan dari hasil wawancara, antara lain: 1) Kualitas informasi: informasi yang dihasilkan oleh sistem masih kurang lengkap. Contohnya template isian pada SIMRS belum lengkap sehingga petugas poli tidak bisa melakukan input data pemeriksaan secara komprehensif dan hasil pemeriksaan laboratorium; 2) Kualitas informasi: informasi yang dihasilkan oleh sistem masih kurang lengkap. Contohnya template isian pada SIMRS belum lengkap sehingga petugas poli tidak bisa melakukan input data pemeriksaan secara komprehensif dan hasil pemeriksaan laboratorium; 3) Kualitas layanan: pengguna masih kesulitan melakukan input data. Contohnya staf bagian laboratorium dan rawat inap saat melakukan input data merasa kesulitan. Menurut staf tersebut program yang digunakan kurang mudah; 4) Intensitas Pengguna dan Pengguna Sistem: pengguna tidak mengimplementasikan sistem informasi manajemen rumah sakit dengan tablet (HP android) yang sudah disediakan oleh pihak manajemen rumah sakit. Contohnya dokter spesialis saat melakukan visite wajib mengisi resum medis dan hasil SOAP dengan menginputkan data hasil visite pasien ke dalam sistem informasi manajemen rumah sakit melalui tablet (HP Android). Namun pada kenyataannya proses tersebut hanya berjalan 1-2 bulan kemudian tidak diisi lagi oleh dokter tersebut karena menurut dokter spesialis tersebut pekerjaannta menjadi tambah lama dan kesulitan melakukan input data hasil visite pasien. Proses yang awalnya sudah menerapkan asuhan medis elektronik kembali ke manual; 5) Kepuasan pengguna: hasil survey peneliti secara subyektifitas dari pengguna sistem informasi 
manajemen rumah sakit dari 9 orang kepala instalasi menyatakan puas 4 orang dan yang tidak puas 5 orang.

Dari masalah diatas muncul dampak negatif yang dirasakan oleh pihak rumah sakit. Dampak negatifnya adalah kualitas informasi yang dihasilkan oleh sistem informasi manajemen rumah sakit tidak berkualitas. Informasi dikatakan tidak berkualitas jika informasi tidak cepat, tidak lengkap, tidak akurat, tidak relevan. Berdasarkan masalah dan dampak negatif diatas terkait dengan sistem informasi manajemen rumah sakit peneliti memiliki solusi untuk menyelesaikan masalah tersebut dengan cara melakukan analisis implementasi sistem informasi manajemen rumah sakit dengan metode DeLone dan McLean. Metode DeLone dan McLean digunakan untuk mendeskripsikan dan menganalisis kualitas sistem, kualitas informasi, kualitas layanan, intensitas pengguna, pengguna sistem, kepuasan pengguna dan net-benefit. Dari penjelasan diatas peneliti memilih metode DeLone dan McLean karena sesuai dengan karakteristik masalah yang ada di Rumah Sakit Paru Jember yaitu kualitas sistem, kualitas informasi, kualitas layanan, intensitas pengguna, pengguna sistem dan kepuasan pengguna.

Sesuai dengan hasil penelitian Roldan \& Leal tahun
2003 tentang executive information system yang menunjukkan bahwa kualitas sistem dan kualitas informasi berpengaruh secara positif terhadap kepuasan pengguna sistem informasi manajemen rumah sakit. Sesuai dengan hasil penelitian Abdul Latih pada tahun 2010 tentang analisa keberhasilan siskohat menggunakan metode DeLone dan McLean menunjukkan bahwa kualitas informasi berpengaruh signifikan terhadap kepuasan pengguna sistem informasi manajemen. Sesuai dengan hasil penelitian Masrek et al pada tahun 2010 tentang keefektifan portal akademik perpustakaan menunjukkan bahwa kualitas sistem, kualitas informasi, kualitas layanan berpengaruh signifikan terhadap kepuasan pengguna sistem informasi manajemen.

DeLone dan McLean (2003) berpendapat bahwa ada beberapa hal penting yang mendorong diperlukannya teknologi informasi di organisasi. Hal ini berkaitan dengan proses pengambilan keputusan yang tidak dilandasi informasi, informasi yang tersedia tidak relevan, informasi yang ada tidak dimanfaatkan oleh manajemen, informasi yang ada tidak tepat waktu, terlalu banyak informasi, informasi yang tersedia tidak akurat, adanya data yang cara pemanfaatannya tidak fleksibel. 
Berdasarkan hal tersebut maka dibutuhkan suatu sistem informasi yang mampu mendukung dalam pengambilan keputusan.

$$
\text { Berdasarkan peraturan }
$$

Menteri Kesehatan Republik Indonesia nomor 82 tahun 2013 yang berisi tentang "Sistem Informasi Manajemen Rumah Sakit" maka rumah sakit yang ada di indonesia mulai menerapkan sistem untuk meningkatkan pelayanan. Sistem informasi manajemen rumah sakit adalah suatu sistem terkomputerisasi yang mampu melakukan pengolahan data secara cepat, akurat, dan menghasilkan sekumpulan informasi yang saling berinteraksi untuk diberikan kepada semua tingkatan manajemen di rumah sakit. Hasil informasi dari data yang telah diolah yaitu berupa laporan, dapat digunakan oleh pengguna dalam mengambil keputusan untuk peningkatan upaya pelayanan kesehatan. Sistem informasi manajemen rumah sakit berfungsi untuk pengendalian mutu pelayanan, pengendalian mutu dan penilaian produktivitas, penyederhanaan pelayanan, analisis manfaat dan perkiraan kebutuhan, penelitian klinis, pendidikan, serta perencanaan dan evaluasi program. Berdasarkan uraian diatas peneliti tertarik untuk melakukan penelitian dengan judul "Analisis Implementasi Sistem Informasi Manajemen Rumah Sakit Dengan
Metode DeLone \& McLean di Rumah Sakit Paru Jember"

\section{Metode}

Bagian ini menjelaskan jenis metode (kualitatif, kuatitatif atau mixed-method) disertai rincian metode pengumpulan data dan metode analisis data yang digunakan. Bagian ini juga dapat menjelaskan perspektif yang mendasari pemilihan metode tertentu.

\subsection{Metode Pengumpulan Data}

Jenis penelitian ini adalah penelitian kuantitatif dengan pendekatan crossectional. Populasi dalam penelitian ini adalah seluruh petugas di rumah sakit yang menggunakan SIMRS sejumlah 180 orang. Sampel dalam penelitian ini adalah sebagian dari populasi yaitu pengguna SIMRS di Rumah Sakit Paru Jember sejumlah 125 orang. Teknik pengambilan sampel dalam penelitian ini menggunakan disproportionate stratified random sampling dengan menggunakan 3 hak akses yaitu top manajemen, midle manajemen, lower manajemen.

Variabel penelitian dalam penelitian ini adalah kualitas sistem, kepuasan pengguna, intensitas pengguna. Data penelitian yang digunakan adalah data primer, data yang diambil langsung oleh peneliti ke responden. Sumber data dalam penelitian ini didapatkan dari kuesioner yang diisi langsung 
oleh responden. Kuesioner penelitian dibuat menyesuaikan dengan indikator 3 variabel penelitian.

\subsection{Metode Analisis Data}

Analisis data dalam penelitian ini menggunakan tahapan 1) uji validitas dan reliabilitas; 2) uji normalitas; 3) uji homogenitas; 4) uji kolinieritas; 5) uji autokorelasi; 6) uji path analysis

\section{Hasil dan Pembahasan}

Penerapan Path Analysis Pengaruh Kualitas Informasi Terhadap Kepuasan Pengguna dan Intensitas Pengguna Menggunakan Metode DeLone \& McLean di Rumah Sakit Paru Jember

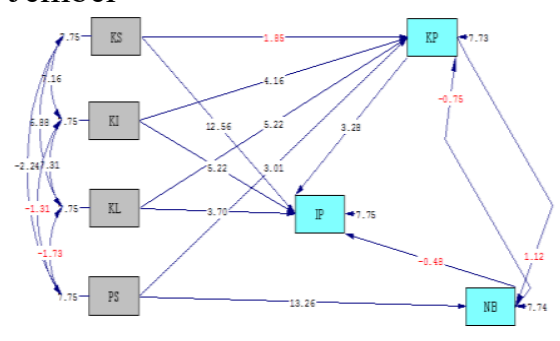

Chi-Square=14.59, df =3, F-value=0.00220, fusen=0.179

Gambar 1 nilai $t$-value program lisrel

Berdasarkan Gambar 1 nilai $\mathrm{T}$-Value program lisrel dapat diketahui bahwa variabel eksogen kualitas informasi memiliki pengaruh yang signifikan terhadap variabel endogen intensitas pengguna yang ditunjukkan dengan nilai $t$ berwarna hitam sebesar 5,66. Variabel eksogen kualitas informasi tidak memiliki pengaruh yang sigifikan terhadap variabel endogen kepuasan pengguna yang ditunjukkan dengan nilai $\mathrm{t}$ berwarna hitam sebesar 4,16.

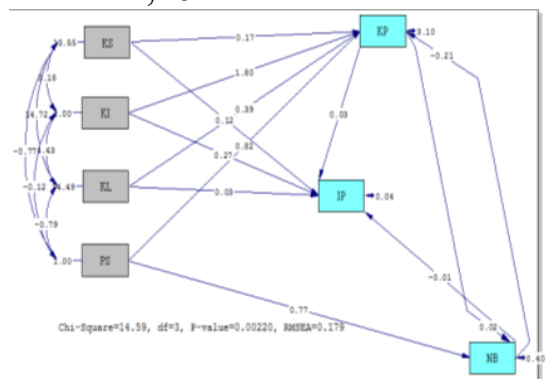

Gambar 2 estimate program lisrel

Berdasarkan Gambar 2 estimate program lisrel dapat diketahui bahwa pengaruh variabel eksogen kualitas informasi terhadap variabel endogen intensitas pengguna memiliki nilai estimasi sebesar 0,27 . Pengaruh variabel eksogen kualitas informasi terhadap variabel endogen kepuasan pengguna memiliki nilai estimasi sebesar 1,80. Estimasi standarized yang diperoleh pada path diagram ini sama dengan output SIMPLIS yang dihasilkan diatas.

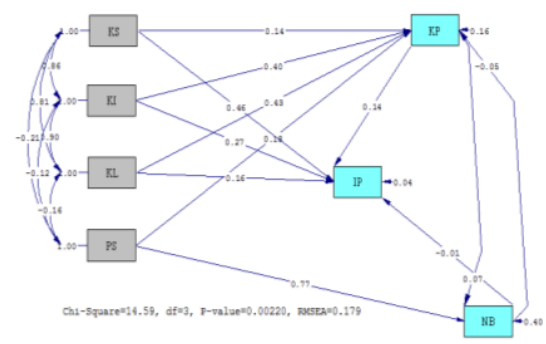

Gambar 3 standarized solution program lisrel 
Berdasarkan Gambar 3 standarized solution program lisrel dapat diketahui bahwa variabel eksogen kualitas informasi memiliki pengaruh yang signifikan terhadap variabel endogen intensitas pengguna sebesar 0,27 atau $27 \%$. Variabel eksogen kualitas informasi memiliki pengaruh yang sigifikan terhadap variabel endogen kepuasan pengguna sebesar 0,40 atau $40 \%$. Tabel 4 merupakan tabel total effect of $\mathrm{X}$ on $\mathrm{Y}$, berikut merupakan tabelnya:

Tabel 1. Total effect of X on Y

\begin{tabular}{lllll}
\hline & KS & KI & KL & PS \\
\hline KP & 0.17 & 1.79 & 0.39 & 0.66 \\
& $(0.09)$ & $(0.43)$ & $(0.07)$ & $(0.17)$ \\
& 1.85 & 4.16 & 5.22 & 3.95 \\
\hline IP & 0.13 & 0.33 & 0.05 & 0.01 \\
& $(0.01)$ & $(0.05)$ & $(0.01)$ & $(0.02)$ \\
& 12.67 & 6.54 & 5.33 & 0.92 \\
\hline NB & 0.00 & 0.03 & 0.01 & 0.78 \\
& $(0.00)$ & $(0.03)$ & $(0.01)$ & $(0.06)$ \\
& 0.96 & 1.09 & 1.10 & 13.30 \\
\hline
\end{tabular}

Berdasaskan tabel output diatas menginformasikan tentang total pengaruh kualitas informasi terhadap kepuasan pengguna adalah 1,80. Nilai tersebut adalah sama dengan pengaruh langsung kualitas informasi terhadap kepuasan pengguna sebagaimana yang ditampilkan oleh output SIMPLIS, karena hubungan kualitas informasi dan kepuasan pengguna adalah langsung dan memiliki hubungan tidak langsung. Sedangkan total pengaruh kualitas informasi terhadap intensitas pengguna adalah sebesar 0,33 yang diperoleh melalui penjumlahan pengaruh langsung kualitas informasi terhadap intensitas pengguna dan pengaruh tidak langsung kualitas informasi terhadap intensitas pengguna. Sehingga, $0,27+0,06=0,33$. Tabel 2 merupakan Indirect effect of $X$ on Y, berikut merupakan tabelnya:

Tabel 2. Indirect effect of $X$ on $Y$

\begin{tabular}{lllll}
\hline & KS & KI & KL & PS \\
\hline KP & 0.00 & -0.01 & 0.00 & -0.16 \\
& $(0.00)$ & $(0.01)$ & $(0.00)$ & $(0.22)$ \\
& -0.51 & -0.53 & -0.53 & -0.75 \\
\hline IP & 0.01 & 0.06 & 0.01 & 0.01 \\
& $(0.00)$ & $(0.02)$ & $(0.01)$ & $(0.02)$ \\
& 1.61 & 2.58 & 2.78 & 0.92 \\
\hline NB & 0.00 & 0.03 & 0.01 & 0.01 \\
& $(0.00)$ & $(0.03)$ & $(0.01)$ & $(0.01)$ \\
& 0.96 & 1.09 & 1.10 & 1.08 \\
\hline
\end{tabular}

Berdasarkan tabel output diatas menginformasikan tentang pengaruh tidak langsung antara variabel. Pengaruh tidak langsung kualitas informasi terhadap intensitas pengguna sebesar 0,06 . Estimasi pengaruh tidak langsung kualitas informasi terhadap kepuasan pengguna tersebut diperoleh melalui perkalian antara nilai estimasi langsung kualitas informasi terhadap kepuasan pengguna (variabel interverning) dan nilai estimasi langsung kepuasan pengguna terhadap intensitas pengguna. Jadi 0,06 diperoleh melalui $1,80 \times 0,03=$ 0,06 . Tabel 3 merupakan tabel total Effect $\mathrm{Y}$ on $\mathrm{Y}$ berikut adalah tabelnya: 
Tabel 3. Total effect $Y$ on $Y$

\begin{tabular}{llll}
\hline & KP & IP & NB \\
\hline KP & 0.00 & -- & -0.21 \\
& $(0.01)$ & & $(0.27)$ \\
& -0.51 & & -0.75 \\
\hline IP & 0.03 & -- & -0.02 \\
& $(0.01)$ & & $(0.02)$ \\
& 3.29 & & -0.74 \\
\hline NB & 0.00 & -- & 0.00 \\
& $(0.00)$ & & $(0.01)$ \\
& 0.96 & & -0.53 \\
\hline
\end{tabular}

Berdasarkan tabel output total effect of Y on Y merupakan keluaran program LISREL yang menginformasikan total pengaruh variabel observed dengan endogen terhadap variabel endogen lainnya. Sehingga, total pengaruh variabel endogen kepuasan pengguna terhadap intensitas penguna adalah sebesar 0,03 sedangkan total pengaruh kepuasan pengguna terhadap netbenefit adalah sebesar 0,02 .

Dari data penelitian di atas peneliti dapat menyimpilkan bahwa kualitas informasi berpengaruh signifikan terhadap kepuasan pengguna. Kepuasan pengguna berpengaruh signifikan terhadap intensitas pengguna. Sehingga bisa ditarik kesimpulan bahwa kualitas informasi berpengaruh langsung terhadap intensitas pengguna.

Variabel kualitas informasi terhadap kepuasan pengguna dalam penelitian ini sesuai dengan hasil penelitian Andika (2016) bahwa kualitas informasi berpengaruh signifikan terhadap kepuasan pengguna. Hasil penelitian Dony (2016) bahwa kualitas informasi berpengaruh signifikan terhadap kepuasan pengguna. Hasil penelitian Stacie (2008) bahwa kualitas informasi berpengaruh signifikan terhadap kepuasan pengguna. Hasil penelitian Muhimmah (2016) bahwa kualitas informasi berpengaruh signifikan terhadap kepuasan pengguna.

Peneliti berpendapat bahwa kesesuaian hasil penelitian ini dengan 4 penelitian sebelumnya dikarenakan Informasi dalam SIMRS sudah sangat jelas karena rekam medisnya sudah elektronik yang terdiri dari format identitas pasien, anamnesis pasien, pemeriksaan umum, pemeriksaan fisik, ICD-10 dan ICD-9CM, rencana terapi, pemeriksaan penunjang, tindakan medis, konsultasi dokter, informasi biaya, riwayat kunjungan, uploader penunjang, uploader dokumen, resum medis, asuhan keperawatan, asuhan farmasi dan hasil pemeriksaan laboratorium. Responden dokter dan perawat juga menyatakan bahwa informasi yang tersedia sangat lengkap, mudah diakses dan mudah dibaca. Namun sistem masih perlu dikembangkan, bahkan bagi user yang belum aktif menggunakan sistem dirasa belum terintegrasi.

Variabel kepuasan

pengguna terhadap intensitas pengguna dalam penelitian ini sesuai dengan hasil penelitian Andika (2016) bahwa kepuasan 
pengguna berpengaruh signifikan terhadap intensitas pengguna. Hasil penelitian Manik (2016) bahwa kepuasan pengguna berpengaruh signifikan terhadap intensitas pengguna. Hasil penelitian Muhimmah (2016) bahwa kepuasan pengguna berpengaruh signifikan terhadap intensitas pengguna. Hasil penelitian Yeni (2015) bahwa kepuasan pengguna berpengaruh signifikan terhadap intensitas pengguna.

Peneliti berpendapat bahwa kesesuaian hasil penelitian ini dengan penelitian sebelumnya dikarenakan Informasi dalam SIMRS sudah sangat jelas karena rekam medisnya sudah elektronik yang terdiri dari format identitas pasien, anamnesis pasien, pemeriksaan umum, pemeriksaan fisik, ICD-10 dan ICD-9CM, rencana terapi, pemeriksaan penunjang, tindakan medis, konsultasi dokter, informasi biaya, riwayat kunjungan, uploader penunjang, uploader dokumen, resum medis, asuhan keperawatan, asuhan farmasi dan hasil pemeriksaan laboratorium. Responden dokter dan perawat juga menyatakan bahwa informasi yang tersedia sangat lengkap, mudah diakses dan mudah dibaca. Karena informasi yang dihasilkan SIMRS dirasa sangat jelas maka pengguna menggunakan SIMRS dalam kegiatan dinas setiap harinya.

\section{Simpulan dan Saran 4.1 Simpulan}

Kualitas informasi

berpengaruh signifikan terhadap kepuasan pengguna dengan nilai berwarna hitam sebesar 4,16. Kepuasan pengguna berpengaruh signifikan terhadap intensitas pengguna dengan nilai berwarna hitam sebesar 3,28. Sehingga bisa ditarik kesimpulan bahwa kualitas informasi berpengaruh langsung terhadap intensitas pengguna

\subsection{Saran}

Kualitas informasi perlu menjadi perhatian penting sehingga memberikan dampak positif baik bagi penyedia layanan kesehatan maupun pasien sebagai konsumen layanan kesehatan

\section{Daftar Pustaka}

Advistasari, Y.D., Lutfan, L. and Pudjaningsih, D., 2015. Evaluasi Sistem Informasi Manajemen Farmasi Menggunakan D\&M IS Success Model Untuk Mendukung Pengelolaan Obat di RSUD Kota Semarang. Journal of Management and Pharmacy Practice, 5(3), pp.211-216.

Barsasella, Diana. 2012. Sistem Informasi Kesehatan. Jakarta: Rineka Cipta.

DeLone, W.H and McLean, E.R. 2003. The DeLone McLean Model Of Information System Succes: A ten-Year Update, Journal of Management Information, Vol. 19, No.4: 9-30.

Delone, W.H. and McLean, E.R., 1992. Information System Succes: The Quest for the 


\section{ISSN : 2354-5852 \\ e-ISSN : 2579-5783}

Dependent Variabel. Information

System Research, 3, pp.60- 95.

Delone, W.H. and McLean, E.R., 2003. The Delone and McLean Model of Information System Succes : A ten-Year Update. Journal of Management Information System, (19:4), pp. 9-30.

DeLone, WH., dan McLean, ER. 1992. Information Systems Success: The Quest for the Dependent Variable. Information System Research, 3(1), 60-95.

Dody \& Zulaikha. 2007. Simposium Nasional Akuntansi X. Pengujian Model DeLone and McLean
Dalam Pengembangan Sistem Informasi Manajemen (Kajian Sebuah Kasus). Unhas Makassar. http://eprints.undip.ac.id/15193/1 /SI-_05.pdf

Hatta, Gemala R. 2008. Manajemen Informasi Kesehatan di Sarana Pelayanan Kesehatan. Jakarta: UI Press.

Huffman, Edna K. 1994. Health Information Management 10th Edition. Berwyn, Illonois: Physicians Record Company.

Jogiyanto. 2007. Model Kesuksesan Sistem Teknologi Informasi. Yogyakarta: Andi. 